\title{
Between dwellings and doors: Spatial perspectives on preaching
}

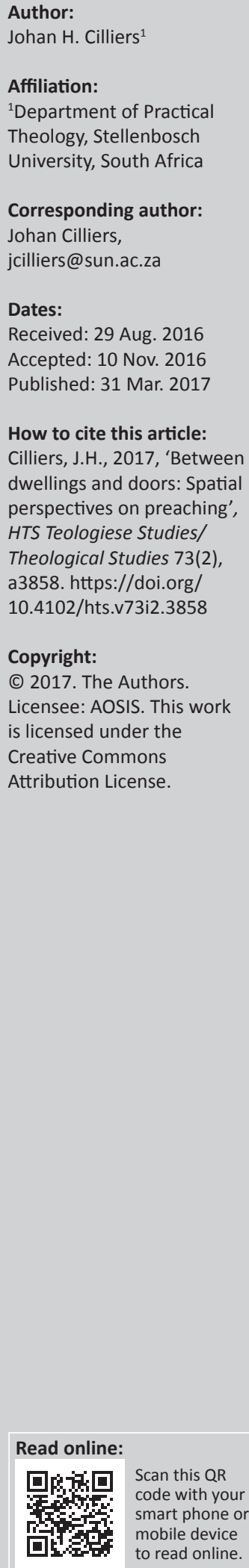

\begin{abstract}
Although many classical works on preaching, especially within the reformed tradition, would take as point of departure the question of understanding, that is, how to do exegesis of a biblical text in such a manner that it makes sense (is understandable) to present-day listeners of sermons, this article opts for an aesthetical approach, which does not exclude the question of intelligibility, but places it within aesthetical frameworks, such as our multi-sensing of space and time. Preaching, in my opinion, entails more than just speaking, hearing and (cognitive) understanding. It calls, inter alia, for a multi-sensory (re)discovery of space and time, within space and time. This article reflects specifically on the spatial dimension of preaching pertaining to experiences of being, or coming, home and, conversely, leaving home, that is, experiencing liminality, as not-being-at-home.
\end{abstract}

\section{I'm coming home ...}

Many definitions of preaching have been and, in fact, could and should be offered (Beach 1999; Cilliers 2004:31; see also Gräb 2013:209). ${ }^{1}$ The act of preaching constitutes a multi-layered event, constantly challenging the borders of our so-called homiletical methodologies. In this article, I venture to take a fundamental human characteristic (or existentialia) as point of departure in my endeavours to define preaching, namely the need and necessity of humans to find, and dwell in, a space called 'home' (my discussion in Cilliers 2016:33).

The understanding of space as 'home' or 'dwelling' has been explored in the phenomenological writings of people like Heidegger, Bachelard, Levinas and Bollnow. For these thinkers, 'home' and 'dwelling' denote more than just another human activity such as working and travelling. Building a house and dwelling in it (being at home) are rather fundamental expressions of human existence. Being human is being at home, is dwelling.

I find the thoughts of Otto Bollnow of particular interest, also in view of preaching (as described, inter alia, in Bollnow 1955; 1961; 2011:135). Briefly put, his understanding of space as home hinges on the fact that although human beings can be characterised as 'fugitives on earth', the phenomenon of dwelling in a home acts as a point of reference, granting the human being a space for anchoring himself or herself tightly to the ground by means of the solid walls of his or her house (Bollnow 1961:33).

Considering the fugitive status of human beings on this earth (or taking a human being's possibility of movements in any direction in the so-called 'lived space' into account), Bollnow asks: 'Where is my real home?' (Bollnow 1961:32). In his endeavour to answer this question, he speaks about home as 'the spatial center of the life of the individual' (Bollnow 1961:33). In fact, a human being 'needs a firm dwelling place if he is not to be dragged along helplessly by the stream of time' (Bollnow 1961:33).

Of course, 'home' can mean different things to different people. A so-called primitive hut can be 'home', and a mansion can be experienced as anything but home, in fact as cold and uninviting. One can feel homeless in a palace and at home in a little house in the Karoo. For me, the word 'home' conjures up images of sitting around the Dover Welcome Stove in the Karoo-kitchen with the rest of the family, while the earth outside lies white with frost. Sensorial memories often paint pictures of 'home': the smell of the soil after a bout of (scarce) rain; the touch of a door handle; the sight of a specific table, bed, chairs ...

1.Most definitions would oscillate between a classic theological definition such as praedicatio verbi dei est verbum dei [preaching of the Word of God is the Word of God] and more anthropologically inclined notions, such as a religious dialogue aimed at indicating or clarifying the meaning of life (Sinndeutung). My own definition of preaching would be the following: Preaching takes place when God's voice is heard through the voice of the text, in the voice of the time (congregational context), through the (unique) voice of the preacher.

Note: This article is published in the section Practical Theology of the Society for Practical Theology in South Africa. 
'Home' entails more than just a geographical space. It also surpasses the mere memory of things. Home 'happens' through encounters, through seeing the faces of others and through the experience of belonging. When home happens, the space between the walls attains a deeper meaning; time loses its linear onslaught. I sense that in this place I can and want to remain forever. Time and space (or rather space-time) attain a deeper meaning of fullness and fulfilling, of arriving and dwelling, of not only searching for meaning, but in fact experiencing, even celebrating that part of meaning that has been disclosed to me - how seemingly minute it also may seem - with others. It is when new meaning dawns in such a way, often indescribable, that it enables one to experience this particular space and this particular time as home.

One could, of course, describe this experience of fulfilment in many ways. In literature research, for instance, Mikhail Bakhtin speaks about chronotope (literally, 'time-space') when referring to the intrinsic connectedness of temporal and spatial relationships that are artistically expressed in literature. To Bakhtin, chronotope expresses the inseparability of space and time, time being the fourth dimension of space (Bakhtin 1981:84). For instance, when reading (good) literature, one sometimes has the feeling that time 'stops' and that we enter 'another world'. We lose track of time and we enter a new space. This is also true of our aesthetical experiences, for instance, when viewing (good) art or listening to music. I am reminded of Mark Twain who once said that the two most important days of one's life are the day that one is born and the day one finds out why. ${ }^{2}$ For me, coming 'home' is finding out why - or rather: finding a space where I can freely ask these fundamental questions: Why am I alive? Why, and where, do I belong?

Perhaps, one of the most striking and classic, aesthetical depictions of a homecoming is still Rembrandt van Rijn's portrayal of the return of the prodigal son (Munz 1954:148; see also my description in Cilliers 2012:149). ${ }^{3}$ In this painting, the essence of welcoming love is concentrated in the hands of the father. While the old man who thought his son was lost to him forever, presses him against his breast, his sadness is transformed into deep gratitude. The prodigal son puts his head against the heart of the father, his own heart beating with sorrow and repentance, but also the relief of being home again. With some imagination, one can hear the unifying of heartbeats, after being separated for such a long time:

In proverbial terms: home is where the heart is.

Or, if you wish: home is where the hearts beat together.

What is significant is the underplayed intensity of the figures, as opposed to the earlier periods of Van Rijn. Figure 1, for example, contributes little on an emotional or artistic level to the painting - except to strengthen the focus on the father's 2.This quote, although well known, has not definitively been sourced to Mark Twain.

3.Viewed 05 July 2016, from www.respree.com. Rembrandt van Rijn actually made various paintings of this biblical scene. The above image is one of his later works and also shows the psychological and artistical development that took place in the artist here there is for example less of a search for dramatic effect through movement than through underplayed intensity of the figures.

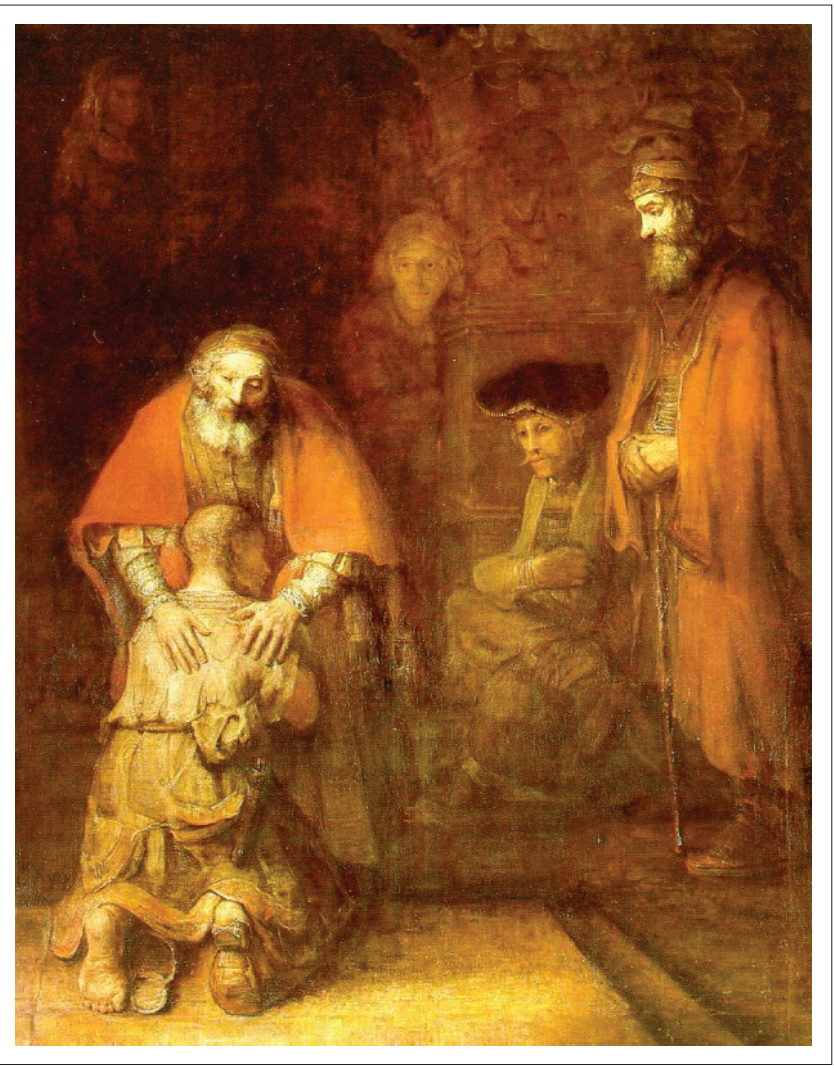

Source: www.respree.com

FIGURE 1: Earlier periods of Van Rijn.

hands (Munz 1954:148). All eyes are fixated on the son, being embraced by the father.

The use of light and darkness is typical, a technique to create the illusion of three-dimensional form - a method known as chiaroscuro. With this the painting almost gains the effect of a sculpture, or more dynamically said: it looks as if the figures approach you from a dark background and your go forwards to meet them. The trajectory of the light determines how the viewer sees the image (Stone 2003:82). In the Prodigal Son of Rembrandt van Rijn, the viewer is invited into the picture, as it were to first become part of the dark background ('the outer darkness'), before you are pulled into the embrace of the father, to the point of light surrounding his blessing hands. Light contrasts darkness; death contrasts life. Cold stands in contrast to warmth, loneliness to community, alienation to salvation, the pigsty to the father's home (Joby 2004). ${ }^{4}$

Linking on to this aesthetical depiction, I venture to describe this feeling of 'coming home' also in theological terms: It is experiencing the fullness, the pleroma, of a given time in a given place. ${ }^{5}$ Pleroma, in the biblical sense of the word, indicates the fulfilment of God's intent in time and space, particularly in Christ. 'In Christ', all things, also cosmological,

4.According to joby, it is amongst other things this use of light that validates the conviction that the paintings by Rembranct van Rijn can be seen as expressions of a Calvinistic aesthetic. For Calvin, God was Spirit, the transcendent and absolute. So how do we know God? According to Calvin, the light of God's glory shines out of heaven upon us, and although only a few rays of it reach us, it is enough that we can see God's beauty and honour him. Rembrandt makes use of light in his paintings to suggest the transcendence, but also the immanence (revelation) of God. In this way, the scene of the homecoming of the prodigal son is bathed in the heavenly light of mercy.

5.One could also say, when this given time and given place unify as kairos. 
are unified and brought to its fruition. ${ }^{6}$ The notion of pleroma has been described in many ways (Van Ruler 1974:72-79). ${ }^{7}$ For me, pleroma indicates God's intent being historically revealed within cosmological context as well as eschatologically concealed within signatory form.

This means that the fullness of experience of an encounter with God is a reality, that is, historically real, but as such also has an effect on things cosmological. Time and space, seen cosmologically, are affected by the reciprocal and historical encounters between God and human beings. But these experiences of fullness of encounters are also preliminary, that is, pleroma is preliminary, awaiting (further) fulfilment, without diluting the fulfilment of the historical dimension. Therefore, these experiences of pleroma are often given to us in the form of signs, fragments and outlines - which could easily be overlooked, and which calls for discernment (Jaspers 1977:234). ${ }^{8}$ In short, one could in fact miss out on being, or coming home - not reading the time correctly, not realising into what space you have been brought.

\section{I'm leaving home ...}

But the notion of home also calls for a new understanding of homelessness. The context in and against which Bollnow spoke about the home as a point of anchoring was the existentialist view of the human being in which the focus is on notions such as despair (Kierkegaard), anxiety (Heidegger) and nausea (Sartre) and in particular the image of a human being as a traveller (homo viator) and as a refugee perpetually under way - being homeless, uprooted. Against these notions, Bollnow postulated the home as a new security (Neue Geborgenheit).

Actually, the word 'security' does not capture the mood of the concept of Geborgenheit. The latter entails more than just safety, for instance, from intruders from outside. It signifies more than living behind burglar bars, in a so-called 'security complex' or 'gated community'. Geborgenheit rather indicates an existential experience of finding and fitting into one's place in this universe, of being comforted and cared for, of healing and happiness. Finding, and dwelling in this (new) security, this Geborgenheit is the very 'essence' of a human being's existence - the security of one's own 'castle' (Bollnow 2011:231ff.). ${ }^{9}$

\section{Cf. Ephesians 1:10.}

7.In the classic works of the Dutch theologian, Arnold van Ruler, we find, for instance, a description of no less than ten characteristics of pleroma (what he calls 'vervulling' description of no less than ten characteristics of pleroma (what he calls 'vervulling,
fulfilment), namely its historical, concealed, signatory, pluralistic, paradoxical, fulfilment), namely its historical, concealed, signatory, pluralistic, paradoxical,
sacramental and cultural, universal, cosmological, ordinary and irresistible dimensions.

8.According to Karl Jaspers, borderline situations, inclusive of awe and doubt, poin towards the true origin of philosophy because they are so closely bound up with the experience of transcendence. This experience, however, is only possible in the enigmatic form of never fully decipherable signs, or as Jaspers calls them, chiffres or 'ciphers'. These chiffres point towards something completely other that can never be fully understood, for instance, also towards God.

9.Bollnow developed his distinct understanding of space within the context of modern notions of infinite, boundless, Cartesian space, which have their origins in new inventions in science and technology. According to him, 'space' is continuously and dialectically constructed between subject and environment, that is, between human being (physical and psychological) and environment. Bollnow pointed out that there seems to be a certain conflict between the meaning of so-called threethat there seems to be a certain conflict between the meaning of so-called three-
dimensional spaces and an anthropological sense of space as described above as 'home' and 'dwelling'. He suggested that the etymology of the German word 'raum'
But, paradoxically, 'home' should also never become a castle! Bollnow argues that although human beings 'carve out of universal space a special and to some extent private space and thus separates inner space from an outer space', this separation may never become absolute (Bollnow 1961:33). Although the walls of the house represent the boundary between inner and outer space, this boundary is and should remain porous. Human beings need the outer space, to make the inner space liveable. Therefore, we need doors and windows in order to have vision, to see the horizon, to step over the threshold into a broader space as contrasted with the narrowness of the house. We need the so-called strangeness of the outside as contrasted with what is known on the inside. We need the experience of distance, of horizon, contrary to the experiences of closeness in the house. The understanding of the horizon as a point of orientation is understood in contrast to the security of the home and hearth. ${ }^{10}$

According to Bollnow, the longing to be at home and the longing to explore the horizon in the distance are two sides of the same coin, which is, in fact, basically the same. It forms part of the innermost nature of humanity to be both anchored and exploring (Bollnow 2011:173). We need to leave the house in order to understand the house. In contrast to the outer space of 'openness, of danger and abandonment', the space of the home provides a protected and hidden area in which the human being 'can be relieved of continual anxious alertness, into which he can withdraw in order to return to himself' (Bollnow 1961:33). ${ }^{11}$

Thus, the boundary between inner and outer space is not set in stone. We can and indeed must continuously cross this boundary. Inside and outside are not just elements in an objective geometrical space to be described along a couple of objective axes. The fact that a house has doors and thresholds and windows acts as an invitation to move in different directions within the 'lived space'. Although the house is an area of security and peace, we cannot remain locked up in our houses, lest they become spaces of imprisonment. Security and danger both belong to the human condition, to the liminal nature of our being.

To sit in front of the fireplace on a cold night, but also to leave through the door when the sun rises - both constitute life. Few people articulate this tension between the comings and

(footnote 9 continues....

(used originally to mean space) corresponds to the word 'raum' (for instance, used by Grimm), which means to make a clearing in the forest with the intention of settling down, to establish a dwelling that is, an anthropological sense of space. For settling down, to establish a dwelling, that is, an anthropological sense of space. Fo him, the latter differs fundamentally from an understanding of cosmic space as infinite, boundless and three-dimensional. Thus, Bollnow's understanding of human space is expressed by polar relations, by two opposite experiences. For him, the anthropological understanding of space as dwelling does have a 'centre', but this differs from the 'centre' of physical space. The centre of the dwelling is constituted by more than mere physical coordinates. The English concept of centre differs from the German term that Bollnow used, namely 'Mitte'. While the English term 'centre' denotes the centricity of a circle, the German word 'Mitte' can also mean being half way on a linear extension or in the centre thereof, that is, in the sense of a threshold between two spaces. It is exactly in this 'Mitte' that physical space and anthropological space converge. The 'Mitte' opens up another field and each space's centre coincides in this field. According to Bollnow, human existence is a kind of rhythm between these two fundamental contrasts, these divergent experiences.

10.'The horizon prevents one from getting lost, and gives one the means to determine one's situation and to work out the path of one's intellect' (Bollnow 2011:176).

11.Each space also has its own particular mood: 'Space has its particular mood, both as an interior space and also as a landscape ... One speaks of a mood of the human temperament as well as of the mood of a landscape or a closed interior space, and both are, strictly speaking, only two aspects of the same phenomenon' (Bollnow 2011:134). 
goings of life, of journeying between dwellings and doors better than Marge Piercy in a poem, titled Doors Opening, Closing on Us (Piercy 2015):
Maybe there is more of the magical
in the idea of a door than in the door itself. It's always a matter of going through into something else. But
while some doors lead to cathedrals arching up overhead like stormy skies and some to sumptuous auditoriums and some to caves of nuclear monsters most just yield a bathroom or a closet. Still, the image of a door is liminal, passing from one place into another one state to the other, boundaries and promises and threats. Inside to outside, light into dark, dark into light, cold into warm, known into strange, safe into terror, wind into stillness, silence into noise or music. We slice our life into segments by rituals, each a door to a presumed new phase. We see ourselves progressing from room to room perhaps dragging our toys along until the last door opens and we pass at last into was.

A couple of years ago, during a boundary experience in my own life, I created an artwork (see Figure 2), titled Dwellings and Doors. To this day, it hangs in my study, reminding me of the seasons of life, of feeling secure, even luxuriously so, but also of taking up my walking stick and becoming a traveller, en route, once again.

\section{Preaching home ... and homelessness}

With these brief (aesthetical, philosophical, theological) comments towards a spatial definition of preaching, we have in fact arrived at the heart of some 'South African realities', as our conference theme challenges us to do. Concepts like 'home', 'homelessness' and 'refugees' are not alien to most South African citizens - on the contrary. In my opinion, preaching could play a fundamental role in the spatial and therefore liminal situating of human beings in terms of these concepts, as described by Bollnow and others. Let me venture a few remarks to elaborate on this.

Firstly, preaching should, in my opinion, be of relevance for the physical needs of humans for houses of mortar and brick. According to Bollnow, dwelling in a home is being human, and since the gospel is all about humanity, this need to be anchored by your house cannot be bypassed or spiritualised, especially also in and through preaching. The issues of homelessness and of land distribution are, for instance, currently of paramount importance in South Africa. One of the effects of apartheid was that thousands of black people were forcefully removed and relocated, often placed in

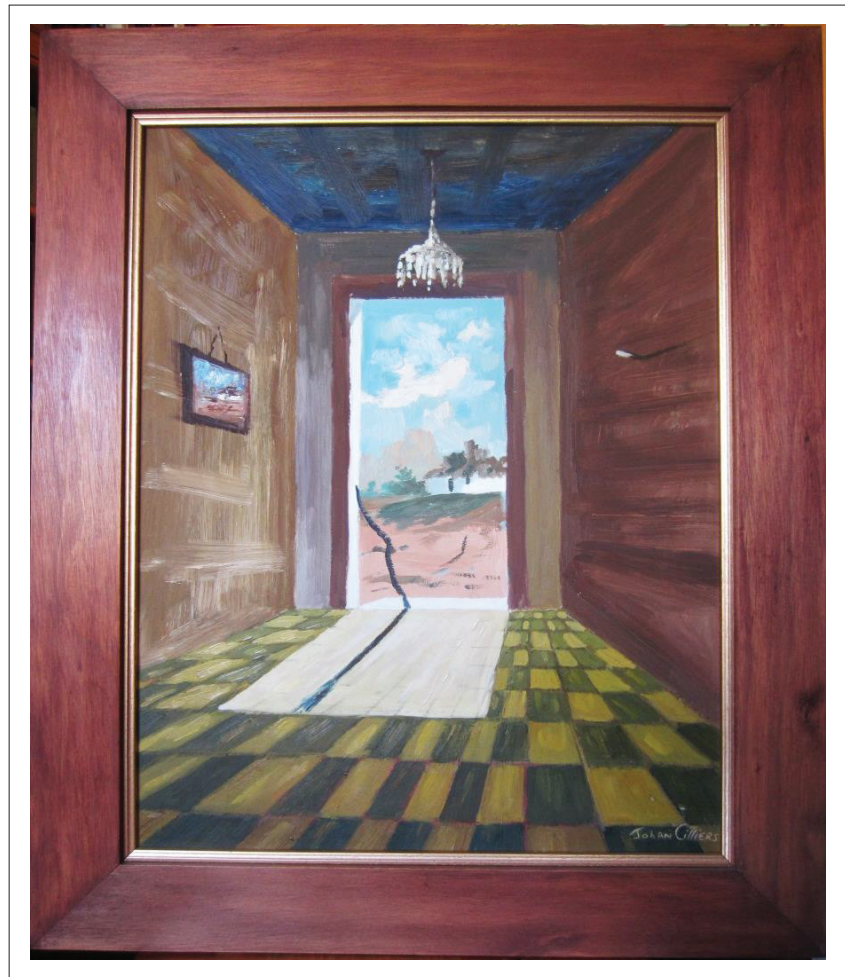

Source: Author's own work

FIGURE 2: Dwellings and Doors.

spaces called 'townships'. They could also be called places of dislocation. Ironically, the Afrikaans word used for townships during the apartheid era was 'lokasie', which means 'location'. It was, however, a place where people were located against their will and should rather have been called 'dislokasies' [dislocations]! These were truly in-between spaces, places of dislocation, of forced migration (Cilliers 2008; 2011). Although many people have attained houses since then, the current data on homelessness in South Africa are still staggering and shocking, to say the least. ${ }^{12}$

But preaching could, again in my opinion and perhaps paradoxically, also play a role in creating a space that is understood as a qualitative concept, constituted by attitudes and values, and not only through geographical coordinates or material realities. ${ }^{13}$ Preaching could deepen

12.It is no easy task to give a concise account of statistics on homelessness in South Africa. A comparison could, however, be drawn between unemployment, poverty and lack of adequate housing. Currently, about $25 \%$ of South Africans are unemployed, with about 16 million being extremely poor. According to Stats SA, $21.7 \%$ of South Africans live in extreme poverty, not being able to pay for basic nutritional requirements; $37.0 \%$ of people don't have enough money to purchase both adequate food items and non-food items so they have to sacrifice food to pay for things like transport and airtime; $53.8 \%$ of people can afford enough food and non-food items but fall under the widest definition of poverty in South Africa, surviving on under R779 per month.

13.There are indeed many paradoxes and tensions linked to the notion of 'home'. On the one hand, our home 'in Christ' reminds us that, in the midst of everything that changes (does not remain), Christ in us, and we in Christ, is the only space that truly 'remains'. Cf. the many references to 'remaining' in the Gospel according to John, for instance in John 6:56; 13:1, 34-35; 15:1-10. But this remaining is never exclusive Christ, not we, determines who belongs to this home, this space. In this sense, it is always strange and foreign, that is, transcending our homes of mortar and brick. This 'remaining' in Christ, although guaranteed, also knows about the possibility of remaining in Christ, although guaranteed, also knows about the possibility of renewed dislocation, for instance in terms of strife between Christians (inhabitants of the home in Christ), and persecution and rejection from those who do not understand the home in Christ. In short: this home-in-Christ is a gift that remains; it is however also a space continuously being expanded by the grace of God; it is also, paradoxically, a space for 'foreigners and sojourners' (cf. 1 Pt 2:11). And furthermore, Christians who inhabit this strange space continuously set up this home-space in whatever concrete home-space they might find themselves in. It is exactly these tensions, these 'liminal experiences of space', inter alia, that need to be articulated in and through preaching. 
our understanding of 'home'. It could aid in the construction of a spiritual space that transcends physical space, a space in which meaning is given and received, and healing and care takes place (Louw 2014:271-279). Preaching could act as a point of reference, of anchoring amidst and against the stream of time, opening up a space for grace that one could in fact call home, including but also transcending home as a structure of mortar and brick - in line with what Bollnow suggested. Preaching can lead one to a place of rest, where I 'belong', where I find my castle.

Dare I venture a first, spatial 'definition' of preaching? Preaching is about belonging - in all the senses of the word. It is about dwelling in a house of mortar and brick, and linked to that: it is about finding and experiencing a new security (Neue Geborgenheit). Or, said in theological and Christological terms: it is about finding your place coram deo, and 'in Christ'. Indeed, do I not find my only comfort in life and death in the fact that I belong to Christ, my faithful Saviour (Heidelberg Catechism; Question/Answer 1)?

Secondly, preaching could also aid in processing the liminal experiences of life, of passing over the threshold, of not being a prisoner in one's own castle. Preaching, in my opinion, holds potential to remind us of the fact that we live in in-between spaces. These in-between spaces are characterised by experiences of presence and absence; it is in these spaces that we not only experience the fullness and abundance of the moment, that is, pleroma, but are also directed towards other dimensions of this fullness, other possibilities of this pleroma not yet experienced (Friedland \& Hecht 2006). It is, in fact, precisely within this (eschatological) tension of presence and absence that the quest for meaning, for significance, is ignited. My second suggestion of a spatial 'definition' of preaching is therefore: Preaching is not only about belonging, but also about becoming. It is about processing and understanding the deep-seated human experience of longing for (a) home, and Home ...

Thirdly, it is a sad fact that liminal experiences (i.e. leaving home) are not always filled with potential for new life and innovative beginnings, but often also with catastrophes and destruction. The plight of modern day refugees - currently estimated at about 65 million, globally - would be a case in point. During the past couple of months, we have been confronted with several catastrophic, global forms of forced migration and asylum seeking that has been, and still is, taking place. Europe experienced its worst migration of people since the Second World War, with thousands flocking from war-torn countries such as Syria, to the shores of especially Greece, Italy and Hungary. In Western Africa, millions of people were uprooted by the violent actions of Boko Haram, with about 1.4 million Nigerians being forced to flee their country. The data about refugees living in South Africa are equally staggering and shocking, to say the least. South Africa is currently experiencing rhythms of migration on an unprecedented scale: an estimated 4 million people have flocked into South Africa since 1994, with all the possible variations of the notion of migration that you can think of: people coming as immigrants, as illegal immigrants, as asylum seekers, as refugees - fleeing from countries where civil wars, poverty, and recently droughts have caused havoc in many communities. ${ }^{14}$

The experience of being a refugee differs fundamentally from the decision, taken out of free will, to leave the house, so to speak. Refugees are forced out of their homes, forced to be homo viators, forced to go in search of a new space that they could call 'home'. The plight of the refugees prompts us to rethink our religious understandings of the human experiences of 'liminality'. There are forms and experiences of 'liminality' that can be good and fruitful, leading to new discoveries and new beginnings, but there are also forms and experiences of liminality that lead to perpetual displacement, and in many cases, death (Franks \& Meteyard 2007:216; Kunin 1998:30). ${ }^{15}$

I was reminded of the moving, but sad poem of Mascha Kaléko:

Wenn ich »Heimweh« sage, sag ich »Traum«.

Denn die alte Heimat gibt es kaum.

Wenn ich Heimweh sage, mein ich viel:

Was uns lange drückte im Exil.

Fremde sind wir nun im Heimatort.

Nur das »Weh«, es blieb.

Das »Heim« ist fort. ${ }^{16}$

In short, refugees are people without home, filled with a longing for home. If home is where the heart is, homelessness could inter alia be described as losing (your) heart - as dramatically illustrated in the sculpture of Frances Bruno Catalano (Figure 3). ${ }^{17}$

People who have lost their home and heart suffer indescribable loss - fundamentally a loss of humanity. This prompts my third endeavour at a 'definition': preaching is not only about belonging, or becoming - it is also about bereaving. Or in more expanded terms, it is about the proclamation of the good news in such a way that those in states of bereavement are guided towards becoming and, hopefully, towards belonging. Preaching is, inter alia, about giving voice to those that are homeless, lamenting their loss of humanity, in the hope of becoming and, eventually, belonging. It is about giving back heart, and in effect, home.

14.It is also no easy task to give a concise account of statistics on refugees in South Africa. According to the Department of Home Affairs, approximately 230000 asylum-seekers were awaiting a decision on their status as refugees at both first asylum-seekers were awaiting a decision on their status as refugees at both firs instance and appeal stages at the end of 2012. The total number of recognised refugees stands at about 65000 . It is more than probable that the number of illegal
immigrants could in fact be far higher (SouthAfrica.info 2014).

15.Essentially liminality implies an ambiguous phase between two situations or statuses. Often this in-between space or liminal displacement is filled with potential and/or danger. It breathes '... a sense of displacement, that sense of being in no man's land, where the landscape appears completely different, there is no discernable road map, and where the journeyer is jolted out of normalcy'. Characteristically the liminal phase is constituted by the convergence or interweaving of qualities of both categories between which it is sandwiched: 'Since the liminal is neither fully one type of space (category) nor the other, it will take on aspects of both; it is this indeterminacy of quality and therefore predictability that creates the aspect of danger'.

16.'When I say 'longing; sorrow for home', I say 'dream'/ Because the old home no longer exists/ When I say 'longing; sorrow for home', I mean a lot:/ that which has been suppressing us for a long time in exile/ we are strangers now in this homeplace/ only the 'sorrow' has remained/the 'home' is gone. Viewed 01 July 2016 , from www.maschakaleko.com/index.php/gedichte/27-heimweh-wonach

17.Titled 'Les Voyageurs' (Travellers), exhibited in Marseilles. Viewed 01 July 2016, from www.boredpanda.com/hollow-sculptures-les-voyageurs-bruno-catalano/ 


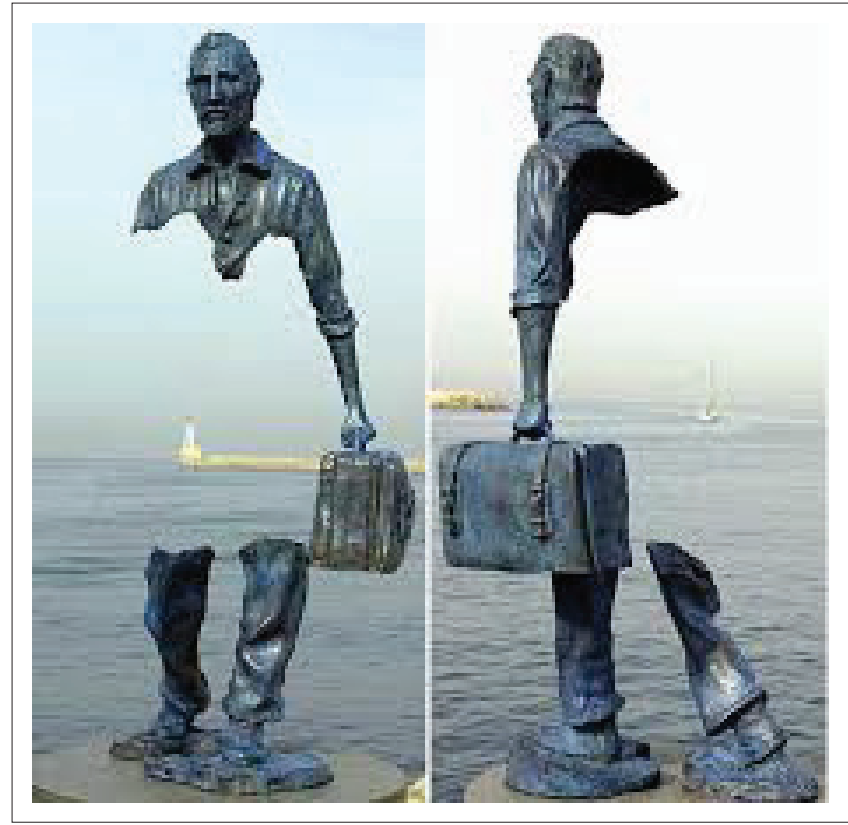

Source: brunocatalano.com (via: mymodernmet)

FIGURE 3: Sculpture of Frances Bruno Catalano.

\section{Acknowledgements \\ Competing interests}

The author declares that he has no financial or personal relationships which may have inappropriately influenced him in writing this article.

\section{References}

Bakhtin, M., 1981, The dialogic imagination: Four essays by M. M. Bakhtin, M. Holquist (ed.), transl. C. Emerson, University of Texas Press, Austin, TX.

Beach, J.M., 1999, 'The real presence of Christ in the preaching of the Gospel: Luther and Calvin on the nature of preaching', Mid-America Journal of Theology 10, 77-134.
Bollnow, O.F., 1955, Neue Geborgenheit: Das Problem einer Überwindung des Existentialismus, Kohlhammer, Stuttgart.

Bollnow, O.F., 1961, 'Lived-space', Philosophy Today 5(1/4), 31-39. http://dx.doi. org/10.5840/philtoday 1961513

Bollnow, O.F., 2011, Human space, J. Kohlmaier (ed.), transl. C. Shuttleworth, Hyphen Press, London.

Cilliers, J.H., 2004, The living voice of the Gospel. Revisiting the basic principles of preaching, Sun Press, Stellenbosch.

Cilliers, J.H., 2008, 'Worshipping in the townships - A case study for liminal liturgy?', Journal of Theology for Southern Africa 132(1), 72-85.

Cilliers, J.H., 2011, 'Between remembrance and restitution: A practical theological investigation into the impact of the Truth and Reconciliation Commission (TRC) within the South African context of religion, diversity, and conflict', in E. Foley (ed.), Religion, diversity and conflict, p. 187, LIT Verlag, Vienna.

Cilliers, J., 2012, Dancing with deity. Re-imagining the beauty of worship, Bible Media, Wellington.

Cilliers, J., 2016, A space for grace. Towards an aesthetics of preaching, Sun Press, Stellenbosch.

Franks, A. \& Meteyard, J., 2007, 'Liminality: The transforming grace of in-between places', The Journal of Pastoral Care and Counseling 61(3), 215-222. http://dx.doi. org/10.1177/154230500706100306

Friedland, R. \& Hecht, R.D., 2006, 'The powers of place', in O.B. Stier \& J.S. Landres (eds.), Religion, violence, memory, and place, p. 35, Indiana University Press, Bloomington, IN.

Gräb, W., 2013, Predigtlehre. Über religiöse Rede, Vandenhoeck \& Rupprecht, Göttingen.

Jaspers, K., 1977, Einführung in die Philosophie, Piper, München.

Joby, C., 2004, 'How does the work of Rembrandt van Rijn represent a Calvinistic Aesthetic?', Theology CVII(835), 22-29.

Kunin, S.D., 1998, God's place in the world. Sacred space and sacred place in Judaism, Cassell, London.

Louw, D.J., 2014, Icons. Imaging the unseen. On beauty and healing of life, body and soul, Sun Press, Stellenbosch.

Munz, L., 1954, Rembrandt, Harry N. Abrams, New York.

Piercy, M., 2015, 'Doors opening, closing on us', Poem-a-Day, Academy of American Poets, viewed 3 July 2016, from https://www.poets.org/poetsorg/poem/doorsopening-closing-us, Copyright (C 2015 by Marge Piercy. Used by permission of the Wallace Literary Agency. First published on 21st May 2015.

SouthAfrica.info, 2014, Refugees and asylum seekers, viewed 6 July 2016, from http:// www.southafrica.info/travel/documents/refugees asylum.htm\#.V3EnOkOkrl W\#ixzz4CMlBEWEf

Stone, K., 2003, Image and spirit. Finding meaning in visual art, Augsburg Books, Minneapolis, MN.

Van Ruler, A.A., 1974, De Vervulling van de Wet. Een Dogmatische Studie over de Verhouding van Openbaring en Existentie, Callenbach, Nijkerk. 